\title{
Persistence of atrazine impact on aneuploidy in Pacific oysters, Crassostrea gigas
}

\author{
K. Bouilly, H. McCombie, A. Leitão and S. Lapègue* \\ IFREMER, Laboratoire de Génétique et Pathologie, 17390 La Tremblade, France \\ * : Corresponding author : slapegue@ifremer.fr Tel.: 33 (0)5 463676 19; Fax: 33 (0)5 46363751
}

\begin{abstract}
:
The widespread use of the herbicide atrazine has incited much research on its toxicity in aquatic systems where it is routinely detected due to runoff from cultivated fields. Moreover, the determination of the genotoxic effect of such pollutants in the marine environment has become a major requirement for ecosystem protection. In the Pacific oyster, Crassostrea gigas, hypodiploid aneuploid cells have regularly been reported. There is a negative correlation between this phenomenon and growth as well as evidence for a genetic basis. A positive relationship between atrazine and aneuploidy was previously demonstrated in C. gigas adults and juveniles. To evaluate the persistence of this impact, our study examined the offspring of the same adult population previously treated with different atrazine doses $(10 \mu \mathrm{g} / \mathrm{l}$ representing a peak value found in a polluted environment and 100 $\mu \mathrm{g} / \mathrm{l})$ and a sweater control. We observed that these offspring exhibited significantly higher aneuploidy levels when their parents had been exposed to atrazine (14.9 to $16.9 \%$ in comparison with the control where the levels ranged from 11.4 to $12.8 \%$ ). In addition, the present study examined the aneuploidy level of a sample of juveniles, previously exposed for three and a half months to the same doses of atrazine, then replaced in non polluted conditions for an additional period of two and a half months and this aneuploidy level remained significantly different between the treatments applied. These results demonstrate the persistence of atrazine impact on Pacific oyster aneuploidy in time within and between generations, indicating that this widely used compound may represent an important factor causing at least medium term damage to genetic material.
\end{abstract}

Keywords: atrazine, pollutant, Pacific oyster, Crassostrea gigas, aneuploidy. 


\section{Introduction}

Atrazine (2-chloro-4-ethylamino-6-isopropyl-amino-s-triazine) is the most commonly used herbicide in the United States and probably the world (US Environmental Protection Agency 1994). It has been used for over 40 years and is currently applied in more than 80 countries to control broad-leaf plants and grassy weeds. In France, atrazine is used mainly on crops to improve yields, particularly that of maize. Atrazine is a potential contaminant of surface and ground water as it is known to have high mobility through soil, so it may easily find its way into the aquatic environment (Marchini et al. 1988). Considering the timing of application and the persistence of atrazine, habitats adjacent to application areas could be chronically exposed to consistently high levels of atrazine that could negatively impact aquatic organisms during their breeding periods. The determination of the genotoxic effect of pollutants in the aquatic environment has become a major requirement for protection of the ecosystem. Many studies about relationships between pollution and immunotoxicity or genotoxicity in vertebrates have been realised, but few studies have examined invertebrates (Dixon 1982; Galloway and Depledge 2001) even though they represent 95\% of the animal species on the earth. Moreover, they play key roles in many ecosystems. The effects of agrochemical pollutants on non-target invertebrate species are therefore important for the environment as a whole. Indeed, these species can be sentinel organisms in the monitoring of aquatic pollution and so allow an evaluation of environmental risk (Rivière 2001). This risk is determined according to a classical approach combining the exposure and the hazard. The exposure is characterised by the calculation of predicted environmental concentrations, and the hazard by ecotoxicity data from tests on different animal and plant species. In consequence, the widespread use of atrazine has generated much research on its toxicity in aquatic systems (Huber 1993; Solomon et al. 1996) as it can induce lethal or sub-lethal effects on aquatic organisms. In Crassostrea gigas, exposure to atrazine at a peak environmental 
concentration $(10 \mu \mathrm{g} / \mathrm{l})$ over a short period resulted in moderate changes in hemocyte aggregation (Auffret and Oubella 1997). Atrazine also directly harmed the growth and development of young C. gigas larvae and indirectly affected veligers by curbing the growth of nanoplankton (Robert et al. 1986). Moreover, Moraga and Tanguy (2000) observed a mortality rate of approximately $60 \%$ to $70 \%$ on C. gigas adults at atrazine concentrations of 100 and $200 \mu \mathrm{g} / \mathrm{l}$ after 2 months of exposure.

Aneuploidy, a cytogenetic abnormality which mainly originates from the nondisjunction of chromosomes during mitosis or meiosis (Bond and Chandley 1983; Martin and Rademaker 1990), is known to be common in bivalve populations (Longwell et al. 1967; Ahmed and Sparks 1970; Dixon 1982; Thiriot-Quiévreux 1986; Martínez-Expósito et al. 1992; Li and Havenhand 1997). In oysters, aneuploidy is observed as the alteration of the normal diploid chromosome number $(2 \mathrm{n}=20)$ in hypodiploid cells with $2 \mathrm{n}=19$, 18 or 17 (Thiriot-Quiévreux et al. 1992). A negative correlation between somatic aneuploidy and growth rate has been reported in the Pacific oyster (Leitão et al. 2001 c), and differential chromosomal susceptibility was observed in aneuploid mitotic metaphase cells (Leitão et al. 2001 b). In spite of this, the causes of this phenomenon are still unclear. Some evidence for the existence of a genetic basis for the control of the level of aneuploidy in C. gigas has been shown (Leitão et al. 2001 a). However, few studies have been made on the influence of environmental factors (such as pollutants) on the level of aneuploidy of bivalves. Dixon (1982) showed that the level of aneuploidy was elevated in Mytilus edulis embryos from a chemically (aromatic hydrocarbons and heavy metals) polluted dock (King’s Dock, Swansea, South Wales, UK). Additionally, in the same species from San Diego Bay, CA, USA, Steinert et al. (1998) showed that there was more DNA damage in areas with a greater exposure to polycyclic aromatic hydrocarbons and heavy metals. Recently, the effect of the herbicide atrazine on aneuploidy in C. gigas was experimentally demonstrated at adult and juvenile 
stages (Bouilly et al. 2003). Indeed, significant differences were shown in aneuploidy level of C. gigas exposed to different atrazine treatments; representing a peak value found in a polluted environment $(10 \mu \mathrm{g} / \mathrm{l})$ and a value ten times higher $(100 \mu \mathrm{g} / \mathrm{l})$ (Bouilly et al. 2003).

In this paper, we investigate whether atrazine has medium term effects on aneuploidy in the Pacific oyster. We studied the aneuploidy level of (1) the offspring of contaminated parents to investigate the impact of atrazine on aneuploidy in the next generation and of (2) previously contaminated juvenile oysters put in non polluted conditions for an additional period to investigate the persistence of impact.

\section{Material and methods}

\section{Initial biological material}

Three-year-old adult Pacific oysters, C. gigas, were purchased from a shellfish farm located in Marennes-Oléron Bay (La Tremblade, Charente-Maritime, France) on the French Atlantic coast in February 2001. Juveniles of the same species were bred and raised at the Institut Français de Recherche pour l'Exploitation de la Mer (IFREMER) hatchery, La Tremblade. They were produced at the beginning of February 2001 by crossing 6 males with 24 females originating from the Seudre river (Charente-Maritime, France). Both adults and juveniles were exposed to atrazine diluted in sea water directly pumped from MarennesOléron Bay as described in Bouilly et al. (2003) prior to the experiments described here. The atrazine (CAS No. 1912-24-9) was supplied by the Institut National de la Recherche Agronomique (Saint-Laurent-de-la-Prée, Charente-Maritime, France) at the concentration of $500 \mathrm{~g} / \mathrm{l}$ (formulated product). Pure seawater was used as a control (treatment 0). The atrazine treatments applied represent one peak value found in a polluted environment $(10 \mu \mathrm{g} / \mathrm{l})$ (treatment 1) (Munschy 1995) and a value ten times higher (100 $\mu \mathrm{g} / \mathrm{l})$ (treatment 2). Indeed, Munschy (1995) found a high concentration in atrazine (7.8 $\mu \mathrm{g} / \mathrm{l})$ in a channel in Brouage 
(Charente-Maritime) which communicates with the Marennes-Oléron Bay, and more recently, in 2003, Munaron (personal communication) found an atrazine concentration of $32 \mu \mathrm{g} / \mathrm{l}$ in Brouage coastal area. Oysters live in these waters, so the value $10 \mu \mathrm{g} / \mathrm{l}$ is an appropriate concentration to use for this study. For each concentration and the control, two replicates were made (A and B). Oysters were acclimated for $6 \mathrm{~d}$ in raceways (containers of circulating seawater measuring $1.65 \times 0.50 \times 0.30 \mathrm{~m}$ ). The experiment was conducted over two months for the adults and three and a half months for the juveniles in closed-circuit raceways with a system of water circulation for oxygenation. Each raceway contained 157 l of seawater, with or without atrazine, which was changed every day and maintained at $19.5^{\circ} \mathrm{C} \pm 1^{\circ} \mathrm{C}$. A volume of $157 \mathrm{ml}$ of atrazine at $10 \mathrm{mg} / \mathrm{l}$ (previously dissolved in distilled water from the initial atrazine solution) for treatment 2 and $100 \mathrm{mg} / \mathrm{l}$ for treatment 3 diluted in $5 \mathrm{l}$ of seawater was added to the corresponding raceways each time the water was changed. Oysters were fed daily with $8 \mathrm{l}$ of Isochrysis galbana $\left(6.10^{6}\right.$ cells $\left./ \mathrm{ml}\right)$ and $3.5 \mathrm{l}$ of Tetraselmis suecica $\left(1.5 .10^{6}\right.$ cells/ml) for each raceway. We can consider that atrazine is unlikely to have affected the phytoplankton used for food in the treatments as Robert et al. (1986) showed that the phytoplanktonic growth was not affected below the atrazine-simazine concentration of 100 $\mu \mathrm{g} / \mathrm{l}$.

Water samples were collected for analysis (Institut de Recherche pour l'Ingénierie de l'agriculture et de l'environnement, Bordeaux, France) throughout the treatment period to verify the atrazine concentrations in the different raceways including the control. For each raceway, $\mathrm{pH}$ and conductivity (salinity) were measured on a homogenised 1-l sample. Highperformance chromatography analyses were then performed. The detection of compounds was carried out at $220 \mathrm{~nm}$. The first sampling was performed just after the addition of atrazine to the raceways for the first time. Concentrations were in agreement with those expected. A second sampling was performed $24 \mathrm{~h}$ after the addition of atrazine in the raceways, just before 
the replacement of the water. At this point, the atrazine concentrations had decreased by about 20\% and new degradation products, such as simazine, déisopropylatrazine and déethylatrazine, had appeared in low concentrations. Sampling was then repeated every $2 \mathrm{~d}$ with a water sample taken at the same point, $24 \mathrm{~h}$ after the addition of the atrazine, in which levels showed a similar pattern of degradation.

\section{Offspring of the previously exposed adults (experiment 1)}

From each raceway of exposed adults described above, we crossed 6 males with 6 females. Gametes were obtained by strip-spawning sexually mature animals. For fertilization, 600 million spermatozoids were added to approximately 3 million ovocytes suspended in $1 \mathrm{l}$ of seawater. We made two replicates for each batch. The fertilised eggs were placed in 30litre fiberglass larval tanks. Larvae from these crosses were reared for approximately 3 weeks under standard conditions (30 l tanks, temperature: $23-24^{\circ} \mathrm{C}$ ) and fed with a mixture of four different phytoplancton species Isochrysis galbana, Pavlova lutheri, Tetraselmis suecica and Chaetoceros calcitrans (25, 10, 2 and 25 cells/ $\mu$ /day respectively). The larval density for each batch was evaluated directly by microscope counts. The larval growth was studied by measuring the size of 50 larvae per batch using an image analysis system every two or three days. The larvae were put in a micro-nursery when they were ready to settle. The aneuploidy of these offspring was studied at four and a half months.

\section{Juveniles (experiment 2)}

In parallel, the juvenile population exposed to atrazine was put into non polluted conditions for an additional period of two and a half months and was then analysed. The different experiments are summarised in Fig. 1. 
Figure 1. Diagram summarising the different experiments: (1) offspring of the adults previously exposed to atrazine and (2) juveniles contaminated by atrazine, then transferred to non polluted conditions.

(1) $\underset{\text { Adults } \quad \mathrm{F} \quad \text { Offspring } \quad \text { A }}{\longrightarrow}$

(2)

\begin{tabular}{|c|c|}
\hline & Juveniles \\
\hline एmamam & Atrazine exposure \\
\hline$\square$ & Non polluted conditions \\
\hline$\longmapsto$ & 1 month \\
\hline
\end{tabular}

\section{Chromosome preparation}

Samples of the offspring of animals exposed to atrazine and the juveniles replaced in non polluted conditions for another two and a half months were analysed. The animals for aneuploidy analysis were incubated for 7-8 $\mathrm{h}$ in seawater containing $0.005 \%$ colchicine for the aneuploidy studies. The gills were then dissected in seawater, treated for 40 minutes in $0.9 \%$ sodium citrate and fixed in a freshly prepared mixture of absolute alcohol-acetic acid (3:1) with two 10 min changes then two 20 min changes. Slides were made from a piece of one individual gill, following the air drying technique of Thiriot-Quiévreux and Ayraud (1982). The preparation was stained for 10 min with Giemsa (4\%, pH 6.8).

\section{Scoring}

Chromosome counts were made directly by microscope observation (Olympus BH2 microscope) on apparently intact and well-spread metaphase cells. We considered the cells with $2 \mathrm{n}=19,18$ or 17 chromosomes as aneuploid. The mean percentage of aneuploidy for each batch of animals was estimated by counting 900 well-spread metaphase cells for experiment 1 on the offspring or 420 metaphase cells for experiment 2 on the juveniles. We studied 30 animals per replicate for experiment 1 and 14 for experiment 2 . We could not 
study the same number of animals for each experiment because we did not have enough juvenile oysters for the second experiment due to unexpected mortality which was unrelated to the treatment.

\section{Statistics}

Since the number of metaphase cells evaluated per individual was the same in all the studied material (30 per individual), it was possible to test the replicate effect using a nested two-way analysis of variance (atrazine concentration and replicate effect). The results between parents and offspring were compared using a three-way analysis of variance (generation (parents or offspring), atrazine concentration and replicate effect). A comparison between the groups of juvenile animals exposed to atrazine and samples of the same groups subsequently put in non polluted conditions for a further period, was made using a three-way analysis of variance (group, atrazine concentration and replicate effect). Statistical analyses of variance were computed using SYSTAT 9.0 by SPSS (Wilkinson 1990). The effect of parental treatment on the offspring hatching rate was analysed with a G-test (Scherrer 1984; Sokal and Rohlf 1995) and on larval growth with the Fisher-Snedecor F-test (Legendre and Legendre 1998).

\section{Results}

Lower hatching rates were observed in the batches where the parents were exposed to atrazine. The hatching rates in the batches where the parents were exposed to 0,10 , and 100 $\mu \mathrm{g} / \mathrm{l}$ of atrazine were $74 \%, 62 \%$ and $56 \%$ respectively (Fig. 2). A G-test revealed a significant difference between the 3 batches. The $G$-values between the 3 batches ( $G=123.35,173.14$ and 70.11) were all greater than the critical value (20.09). A Fisher-Snedecor F-test revealed that the different larval growth series were correlated following the same growth law (Fig. 3). 
Figure 2. Hatching rate (\%) of the offspring of oysters previously exposed to different atrazine concentrations (0; 10 ; and $100 \mu \mathrm{g} / \mathrm{l})$. Bars indicate standard deviation of the mean.

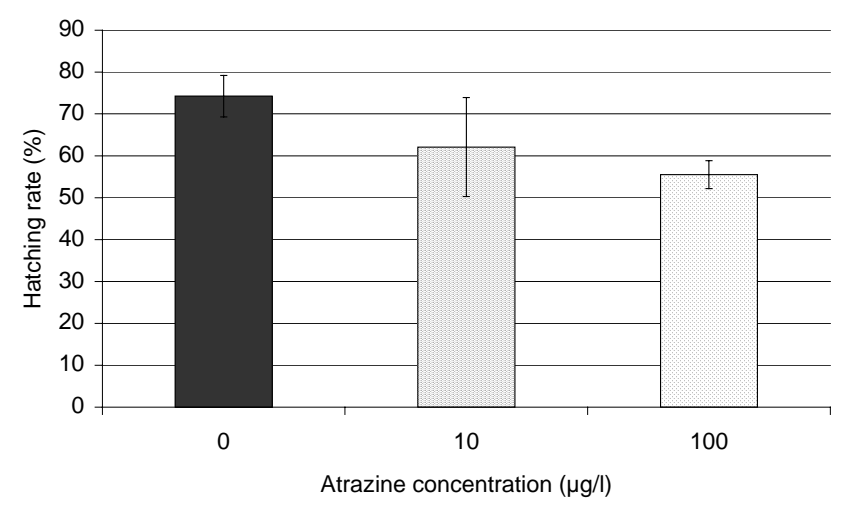

Figure 3. Size $(\mu \mathrm{m})$ of larvae bred from parental oysters previously exposed to different atrazine concentrations $(0 ; 10$; and $100 \mu \mathrm{g} / \mathrm{l})$. Bars indicate standard deviation of the mean.

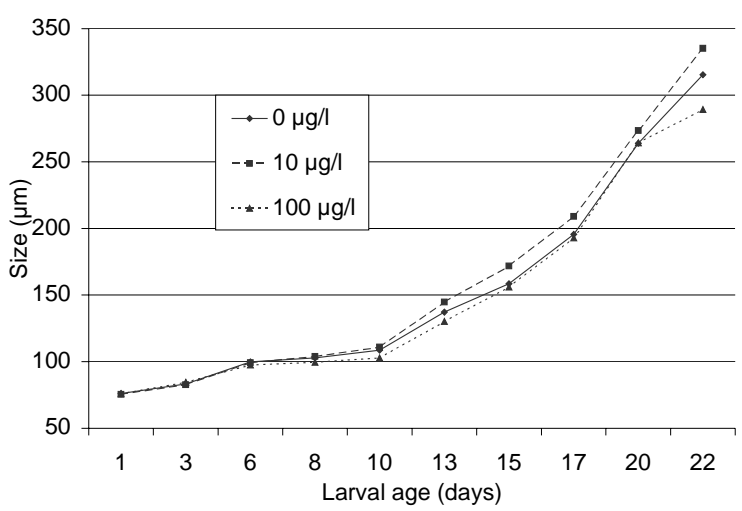

The $F$-values between the 3 batches ( $F=69.33,17.25$ and 11.97) were all greater than the critical value (9.38). The R-values were 0.9920, 0.9968 and 0.9954 . The offspring of previously exposed oysters did not show any difference in larval growth, however, the hatching rate differed significantly. 
The aneuploidy results obtained for the offspring are presented in Table 1. Aneuploidy is a phenomenon frequently observed in natural oyster populations at a low level which explains its presence in the control. The levels for treatment 0 (control), 1 (10 $\mu \mathrm{g} / \mathrm{l})$, and 2 (100 $\mu \mathrm{g} / \mathrm{l}$ ) ranged from 11.4 to $12.8 \%, 15.7$ to $16.4 \%$, and 14.9 to $16.9 \%$ respectively. The statistical analysis showed that aneuploidy level was not significantly different between the replicates $(F=0.711, p=0.400)$. However treatment effect was significant $(F=6.503, p=$ 0.002). The aneuploidy levels for the parents had previously been shown to be significantly different between the treatments (Bouilly et al. 2003). When comparing aneuploidy between parents and offspring (Fig. 4), statistical analysis revealed no significant differences ( $F=$ 0.085, $p=0.771)$. 
Figure 4. Comparison of mean percentage aneuploidy between parents exposed to atrazine and their offspring according to the different atrazine treatments of the parents: treatments $0 \mathrm{~A}, 0 \mathrm{~B}$ (control $0 \mu \mathrm{g} / \mathrm{l}$ ); treatments $1 \mathrm{~A}$, $1 \mathrm{~B}(10 \mu \mathrm{g} / \mathrm{l})$; and treatments 2A, 2B $(100 \mu \mathrm{g} / \mathrm{l})$. Bars indicate standard deviation of the mean.

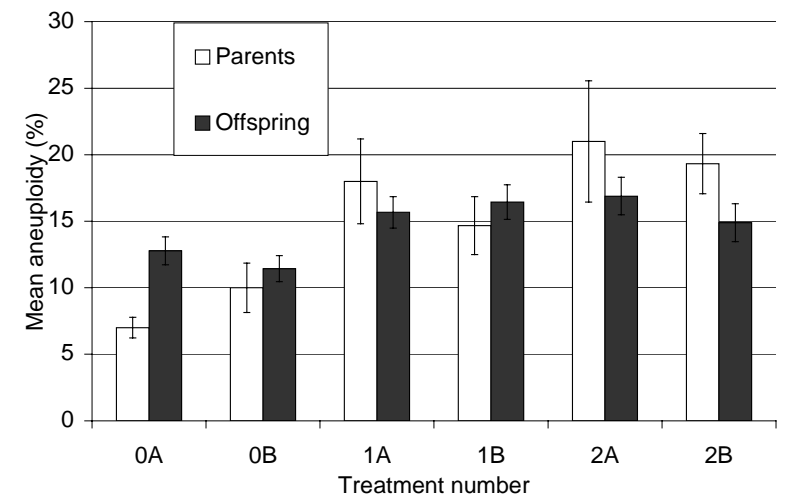

Table 1. Observed aneuploidy of the offspring of parental Pacific oysters Crassostrea gigas exposed to different atrazine treatments: treatments $0 \mathrm{~A}, 0 \mathrm{~B}$ (control $0 \mu \mathrm{g} / \mathrm{l})$, treatments $1 \mathrm{~A}, 1 \mathrm{~B}(10 \mu \mathrm{g} / \mathrm{l})$ and treatments $2 \mathrm{~A}, 2 \mathrm{~B}(100$ $\mu \mathrm{g} / \mathrm{l}$ ) and observed aneuploidy of juveniles contaminated by atrazine then transferred to non polluted conditions for an additional period of two and a half months. Thirty metaphase cells per animal were studied. Standard error of the mean is indicated in parentheses.

\begin{tabular}{llllllll}
\hline Population & Treatment & Number of & \multicolumn{5}{c}{ Total cells observed } \\
& number & animals studied & $2 \mathrm{n}=20$ & $2 \mathrm{n}=19$ & $2 \mathrm{n}=18$ & $2 \mathrm{n}=17$ & aneuploidy (\%) \\
\hline Offspring & 0A & 30 & 785 & 64 & 32 & 19 & $12.8(1.05)$ \\
Offspring & 0B & 30 & 797 & 57 & 26 & 20 & $11.4(0.98)$ \\
Offspring & 1A & 30 & 759 & 88 & 33 & 20 & $15.7(1.19)$ \\
Offspring & 1B & 30 & 752 & 75 & 41 & 32 & $16.4(1.30)$ \\
Offspring & 2A & 30 & 748 & 96 & 35 & 21 & $16.9(1.41)$ \\
Offspring & 2B & 30 & 766 & 75 & 40 & 19 & $14.9(1.43)$ \\
Juvenile & 0A & 14 & 376 & 19 & 11 & 14 & $10.5(1.48)$ \\
Juvenile & 0B & 14 & 377 & 25 & 12 & 6 & $10.2(1.62)$ \\
Juvenile & 1A & 14 & 350 & 33 & 24 & 13 & $16.7(1.60)$ \\
Juvenile & 1B & 14 & 353 & 27 & 26 & 14 & $16.0(2.19)$ \\
Juvenile & 2A & 14 & 340 & 51 & 17 & 12 & $19.0(2.05)$ \\
Juvenile & 2B & 14 & 324 & 50 & 27 & 19 & $22.9(1.81)$ \\
\hline
\end{tabular}


The aneuploidy results obtained for the study of the contaminated juvenile oysters transferred to non polluted conditions are also summarised in Table 1. The aneuploidy levels for treatment 0,1 , and 2 ranged respectively from 10.2 to $10.5 \%, 16$ to $16.7 \%$, and 19 to $22.9 \%$ respectively. They were not significantly different between the replicates $(F=0.416, p$ $=0.521)$, however, treatment effect was significant $(F=17.242, p<0.001)$. The aneuploidy levels of the juveniles contaminated by atrazine for three and a half months, with no period in non polluted conditions, had also been found to be significantly different according to the atrazine concentration (Bouilly et al. 2003). When comparing aneuploidy between these contaminated juveniles and the ones transferred for two and a half months to non polluted conditions (Fig. 5), statistical analysis showed no significant differences $(F=0.546, p=$ 0.461).

Figure 5. Comparison of mean percentage aneuploidy between juveniles contaminated by atrazine and a sample of the same population transferred to non polluted conditions for an additional period of two and a half months according to the different atrazine treatments: treatments $0 \mathrm{~A}, 0 \mathrm{~B}$ (control $0 \mu \mathrm{g} / \mathrm{l})$; treatments $1 \mathrm{~A}, 1 \mathrm{~B}(10 \mu \mathrm{g} / \mathrm{l})$; and treatments $2 \mathrm{~A}, 2 \mathrm{~B}(100 \mu \mathrm{g} / \mathrm{l})$. Bars indicate standard deviation of the mean.

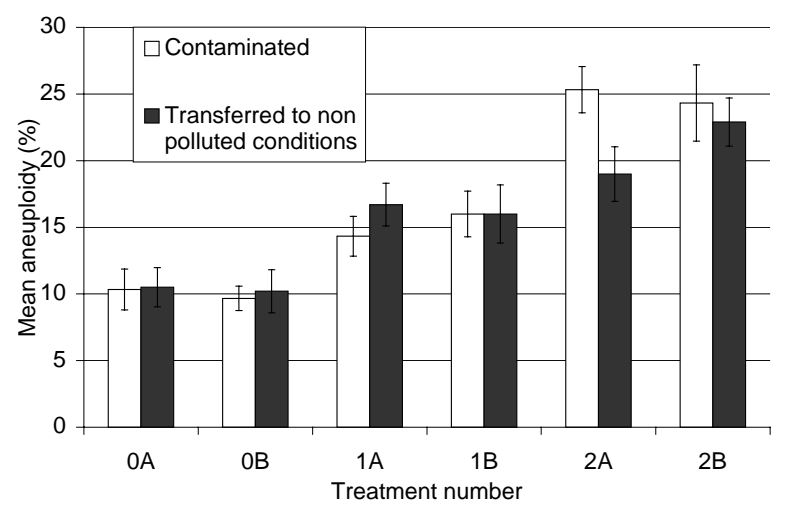

\section{Discussion}

The investigation of the persistence of atrazine impact on aneuploidy in the Pacific oyster is of particular importance since atrazine may cause irreversible damage to genetic material. The precise causes of aneuploidy are still unclear but genetic and environmental 
factors have been shown to be involved in its origin ( Dixon 1982; Bond and Chandley 1983; Verma 1990; Leitão et al. 2001 a; Bouilly et al. 2003).

Considering the timing of application and the persistence of atrazine in habitats adjacent to application areas, pollution could negatively impact aquatic organisms during the breeding periods. Our first experiment is therefore important because the maturation of the parental adults occurred during atrazine exposure. We examined the offspring of an oyster population which had been exposed to atrazine for two months and saw a significant increase of aneuploidy level at the two tested concentrations in comparison with the control treatments. A positive dose-dependent correlation between atrazine and aneuploidy was already established for C. gigas adults and juveniles (Bouilly et al. 2003). Moreover, some evidence has been found for a heritable genetic basis for the control of aneuploidy level in C. gigas (Leitão et al. 2001 a). In this previous study, the possible inheritance of the level of aneuploidy was studied in four full-sib progenies originating from crosses within and between two different populations with contrasting levels of aneuploidy, and a genetic difference in aneuploidy could be attributed to the origin of the parental populations since significant differences in aneuploidy were observed between progenies, based on individuals of the same weight.

Statistical analysis revealed no significant differences when comparing aneuploidy between parents and offspring in our study. In fact, the offspring from contaminated parents also showed higher aneuploidy levels than the offspring of controls. This result clearly shows that the observed atrazine impact on Pacific oyster aneuploidy persists to the next generation. Two hypothesis could be suggested: firstly, that this is an induced heritable effect or, secondly, that the negative effect was transmitted via the maternal egg reserves during larval development. It would be interesting to study the aneuploidy earlier in development, especially at larval stages, to know at what point the phenomenon appears. Our present results 
support the genetic basis for aneuploidy level in the same way as Leitão et al. (2001 a) in that the parents with higher aneuploidy have offspring of higher aneuploidy.

In our study, the presence of atrazine in the environment of the parents had an effect on the hatching rate of their offspring but not on subsequent larval growth. Robert et al. (1986) demonstrated the toxicity of atrazine on the formation and growth of young larvae of C. gigas. They observed abnormal larval growth beyond $500 \mu \mathrm{g} / \mathrm{l}$, and mortality beyond 1000 $\mu \mathrm{g} / \mathrm{l}$. This positive result, compared to our own, was probably found because the larvae themselves were directly exposed to atrazine, and because the concentrations used were several times higher. Nevertheless, if the parents in our study had been exposed to atrazine for longer, this may have influenced the larval or juvenile growth. It would also be interesting to directly expose larvae to different atrazine treatments from the beginning of their development to access the effects of atrazine on aneuploidy during the larval farming and in subsequent juvenile and adult stages.

In the present study, we also showed that the effects of atrazine persist in the absence of exposure. Significant differences in aneuploidy levels had already been observed in a juvenile population of $C$. gigas exposed to atrazine for three and a half months (Bouilly et al. 2003). We have now shown that the aneuploidy levels of a sample of the same population transferred to non polluted conditions for an additional period of two and a half months remained significantly different between the treatments applied. This result could indicate that the genetic damage caused by an exposure to atrazine is irreversible. However, we only left the juvenile oysters in non polluted conditions for two and a half months, a longer period in a clean environment could show us if reversibility of aneuploidy increases as cells are replaced. Marine invertebrates accumulate atrazine essentially by filtering water (Moraga and Tanguy 2000). The compound does not bioaccumulate appreciably (Solomon et al. 1996) although some bioconcentration of atrazine by fish (Solomon et al. 1996), frogs (Allran and Karasov 
2001) and algae (Shelton and Miller 2002) has already been established. Atrazine is quite water soluble and would be rapidly exchanged upon the removal of the exposure, although if oysters accumulate atrazine but do not have mechanisms of detoxification, genetic damage could not be repaired even if the cells were replaced. Very few data are available about the accumulation of atrazine in oysters. Lehotay et al. (1998), in Chesapeake Bay, did not detect atrazine in oysters even when the concentration in the water was $0.432 \mu \mathrm{g} / \mathrm{l}$, although this concentration is lower than those we tested. To our knowledge, no detoxification process for this compound has yet been identified. We also might have irreversible genetic damage via gene expression. Because toxic substances have the potential to damage bivalve DNA (Steinert et al. 1998; Dixon and Wilson 2000), they might therefore damage genes and their expression.

In conclusion, our results demonstrate the persistence of the impact of atrazine on Pacific oyster aneuploidy in time, both within and between generations and also seem to confirm the genetic basis previously found for this phenomenon. Although these effects need to be tested in the natural environment, they are potentially important for the oyster aquaculture industry and management of resources because the lowest atrazine level we tested represents realistic potential exposure (a value 3 times higher has already been observed in Marennes-Oléron Bay (Munaron, personal communication), but such concentrations are not observed very frequently in marine and estuarine environments). Moreover, in the natural environment, the length of exposure might be quite different from that used in our study because of tidal flushing and cycling in the systems, and thus the effect could be smaller. Our findings support legislation limiting the use of atrazine in zones adjacent to shellfish farms. To expand on these results, the next steps will be to study the aneuploidy level of (1) the third generation to investigate the genetic basis of this phenomenon and the inheritance between generations, (2) oysters kept in non polluted conditions for a longer additional period after 
their contamination to have a better understanding of the extent of reversibility of this phenomenon in time and (3) oysters exposed to atrazine in early larval stages.

\section{Acknowledgements}

Part of this research was supported by the Conseil Général of Charente-Maritime and the Région Poitou-Charentes (Plan Etat-Région 2001-RPC-A-212 and 2002-RPC-A-180). We thank R. Ben Hamadou for statistical analysis. All experiments comply with French law.

\section{References}

Ahmed M, Sparks AK (1970) Chromosome number, structure and autosomal polymorphism in the marine mussels Mytilus edulis and Mytilus californianus. Biol Bull 138: 1-13

Allran JF, Karasov WH (2001) Effects of atrazine on embryos, larvae and adults of anuran amphibians. Environ Toxicol Chem 20: 769-775

Auffret M, Oubella R (1997) Hemocyte aggregation in the oyster Crassostrea gigas: in vitro measurement and experimental modulation by xenobiotics. Comp Biochem Physiol 118A(3): 705-712

Bond DJ, Chandley AC (1983) Aneuploidy. Oxford Monographs on Medical Genetics No. 11. Oxford University Press, Oxford, UK.

Bouilly K, Leitão A, McCombie H, Lapègue S (2003) Impact of atrazine on aneuploidy in Pacific oysters, Crassostrea gigas. Environ Toxicol Chem 22: 219-223 
Dixon DR (1982) Aneuploidy in mussel embryos (Mytilus edulis L.) originating from a polluted dock. Mar Biol Lett 3: 155-161

Dixon DR, Wilson JT (2000) Genetics and marine pollution. Hydrobiologia 420: 29-43

Galloway TS, Depledge MH (2001) Immunotoxicity in invertebrates: measurement and ecotoxicological relevance. Ecotoxicology 10: 5-23

Huber N (1993) Ecotoxicological relevance of atrazine in aquatic systems. Environ Toxicol Chem 12: 1865-1881

Legendre P, Legendre L (1998) Numerical ecology. Elsevier Science BV, Amsterdam, The Netherlands.

Lehotay SJ, Harman-Fetcho JA, McConnell LL (1998) Agricultural pesticide residues in oysters and water from two Chesapeake Bay tributaries. Marine Pollut Bull 37: 32-44

Leitão A, Boudry P, McCombie H, Gérard A, Thiriot-Quiévreux C (2001 a) Experimental evidence for a genetic basis to differences in aneuploidy in the Pacific oyster (Crassostrea gigas). Aquat Living Resour 14: 233-237

Leitão A, Boudry P, Thiriot-Quiévreux C (2001 b) Evidence of differential chromosome loss in aneuploid karyotypes of the Pacific oyster, Crassostrea gigas. Genome 44: 735-737 
Leitão A, Boudry P, Thiriot-Quiévreux C (2001 c) Negative correlation between aneuploidy and growth in the Pacific oyster Crassostrea gigas: ten years of evidence. Aquaculture 193: $39-48$

Li XX, Havenhand JN (1997) Karyotype, nucleolus organiser regions and constitutive heterochromatin in Ostrea angasi (Molluscae: Bivalvia): evidence of taxonomic relationships within the Ostreidae. Mar Biol 127: 443-448

Longwell AC, Stiles SS, Smith DG (1967) Chromosome complement of the American oyster Crassostrea virginica as seen in meiotic and cleaving eggs. Can J Gen Cyt 9: 845-856

Marchini S, Passerini L, Cesareo D, Tosato ML (1988) Herbicidal triazines: acute toxicity on Daphnia, fish and plants and analysis of its relationships with structural factors. Ecotoxicol Environ Saf 16: 148-157

Martin RH, Rademaker A (1990) The frequency of aneuploidy among individual chromosomes in 6,821 human sperm chromosome complements. Cytogenet Cell Genet 53: $103-107$

Martínez-Expósito MJ, Martínez-Lage AA, Pasantes JJ, Méndez J (1992) A preliminary study of aneuploidy in natural populations in the genus Mytilus. Cuadernos da Area de Ciencias Mariñas, Seminario de Estudos Galegos 6: 49-55

Moraga D, Tanguy A (2000) Genetic indicators of herbicide stress in the Pacific oyster Crassostrea gigas under experimental conditions. Environ Toxicol Chem 19: 706-711 
Munschy C (1995) Comportement géochimique des herbicides et de leurs produits de dégradation en milieu estuarien et marin côtier. PhD thesis. Université de Paris 6, Paris, France.

Rivière JL (2001) Ecotoxicological and toxicological aspects of pesticides: from regulatory risk assessment to environmental monitoring. Pesticides transfert diagnosis and corrective solutions, Cemagref, Antony, France, no. HS, pp 23-27

Robert R, His E, Maurer D (1986) Toxicité d’un desherbant, l’atrazine-simazine, sur les jeunes stades larvaires de Crassostrea gigas et sur deux algues fourrages Isochrysis affgalbana et Chaetoceros calcitrans. Haliotis 15: 319-325

Scherrer B (1984) Biostatistique. Gaëtan Morin, Montréal, Canada.

Shelton AD, Miller MC (2002) Herbicide bioconcentration in Cladophora glomerata: atrazine removal in a eutrophic agricultural river. Hydrobiologia 469: 157-164

Sokal RR, Rohlf FJ (1995) Biometry. Freeman WH \& Company, New York, NY, USA.

Solomon KR, Baker DB, Richards RP, Dixon KR, Klaine SJ, La Point TW, Kendall RJ, Weisskopf CP, Giddings JM, Giesy JP, Hall LW Jr, Williams WM (1996) Ecological risk assesment of atrazine in North American surface waters. Environ Toxicol Chem 15: 31-76 
Steinert SA, Streib-Montee R, Leather JM, Chadwick DB (1998) DNA damage in mussels at sites in San Diego Bay. Mutat Res 399: 65-85

Thiriot-Quiévreux C (1986) Etude de l’aneuploïdie dans différents naissains d’Ostreidae (Bivalvia). Genetica 70: 225-231

Thiriot-Quiévreux C, Ayraud N (1982) Les caryotypes de quelques espèces de bivalves et gastéropodes marins. Mar Biol 70: 165-172

Thiriot-Quiévreux C, Pogson GH, Zouros E (1992) Genetics of growth rate variation in bivalves: aneuploidy and heterozygosity effects in a Crassostrea gigas family. Genome 35: $39-45$

US Environmental Protection Agency (1994) Pesticides industry sales and usage: 1992 and 1993 market estimates. EPA 733-K-94-001. Washinghton, DC.

Verma RS (1990) The Genome. VCH, New York, NY, USA.

Wilkinson L (1990) SYSTAT: The System for Statistics. SYSTAT, Evanston, IL, USA. 